УДК 355.541.1:351.741

DOI: https://doi.org/10.32631/pb.2021.1.09

\title{
ВІТАЛІЙ ВОЛОДИМИРОВИЧ ФЕДОРОВ,
}

Харківський національний університет внутрішніх справ;

https://orcid.org/0000-0001-6312-4746,

e-mail: ognevaya_podgotovka@ukr.net;

\section{ОЛЬГА БОРИСІВНА ПІСКУНОВА,}

Харківський національний університет внутрішніх справ;

https://orcid.org/0000-0002-7221-4855,

e-mail: ognevaya_podgotovka@ukr.net

\section{РОЛЬ ПРАКТИЧНОЇ СТРІЛЬБИ В СИСТЕМІ ВОГНЕВОЇ ПІДГОТОВКИ ПОЛІЦЕЙСЬКИХ: ПСИХОЛОГІЧНА СКЛАДОВА}

\begin{abstract}
Розглянуто перспективи впровадження методик і технік практичної стрільби в систему спеціальної підготовки поліцейських. Окреслено низку факторів, які впливають на ефективність і результативність вогневого контакту. Зазначено, що вогнева підготовка поліцейського має не тільки прищеплювати первинні навички поводження з вогнепальною зброєю, але й формувати сталі алгоритми дій у тих чи інших типових ситуаціях. Деякі положення цієї статті уже були висловлені в доповіді під час Міжнародної науково-практичної конференції «Шлях успіху і перспективи розвитку (до 26 річниці заснування Харківського національного університету внутрішніх справ)».

Ключові слова: вогнева підготовка, вогневий контакт, психологічна готовність до стрільби, застосування вогнепальної зброї поліцейськими, практична стрільба, вогнепальна зброя.
\end{abstract}

Оригінальна стаття

\section{Постановка проблеми}

Застосування вогнепальної зброї поліцейськими відповідно до законодавства $є$ крайнім заходом примусу. Це означає, що на практиці поліцейський має вичерпати всі інші заходи або переконатися, що вони не будуть дієвими у ситуації, що склалася. Проте дуже часто поліцейські не застосовують вогнепальну зброю навіть тоді, коли це необхідно зробити або ж їхня поведінка $є$ тактично неправильною, що найчастіше призводить до тяжких наслідків для життя або здоров'я поліцейського. Причиною цього $\epsilon$, зокрема, i психологічна неготовність до застосування вогнепальної зброї.

\section{Стан дослідження проблеми}

Психології застосування вогнепальної зброї присвячено багато публікацій, зокрема таких учених: В. Андросюка, В. Афанасьєва, О. Бандурки, I. Веремеєнка, Л. Казміренка, А. Столяренка, Г. Юхновця та ін. Так, Ю. Волков розглядає психологічні аспекти застосування поліцейськими вогнепальної зброї на ураження. При цьому дослідник серед негативних наслідків такого вогневого контакту називає недостатню психологічну підготовленість [1]. Е. Чеботарьов акцентує увагу на специфіці за- стосування вогнепальної зброї в екстремальних умовах [2]. Спробу визначити проблеми психічної травматизації поліцейських здійснив М. Логачов [3]. Проте більшість публікацій, присвячених психологічним аспектам застосування вогнепальної зброї, лише окреслюють проблеми, та не пропонують шляхи їх вирішення.

\section{Мета і завдання дослідження}

Метою статті $\epsilon$ аналіз факторів, що впливають на стан психологічної готовності поліцейського до застосування вогнепальної зброї під час несення служби, та вироблення рекомендацій, які б сприяли формуванню стану психологічної готовності з урахуванням особливостей практичної стрільби.

На досягнення вказаної мети спрямовані такі завдання: визначити внутрішні та зовнішні фактори, які впливають на поведінку поліцейського у ситуаціях необхідного застосування вогнепальної зброї; накреслити можливі шляхи усунення негативних і способи посилення позитивних факторів, що впливають на психологічний стан працівника поліції в ситуації застосування вогнепальної зброї, з урахуванням рекомендацій i порад практичної стрільби. 
Наукова новизна дослідження полягає в теоретичному обгрунтуванні адаптації можливостей практичної стрільби до системи навчальної та службової підготовки поліцейських, які б усували вплив психологічного стану на результативність вогневого контакту.

\section{Виклад основного матеріалу}

Застосування вогнепальної зброї під час виконання службових обов'язків сьогодні ледь не повсякденна практика кожного поліцейського. Однак непоодинокими є випадки настання небажаних наслідків вогневого контакту. Так, за повідомленням Департаменту комунікації Національної поліції України, за перші два з половиною роки існування цього органу виконавчої влади під час несення служби загинули 24 й були поранені 1197 поліцейських (із них у зоні проведення ООС загинули лише 4 й отримали поранення 38 працівників поліції) ${ }^{1}$.

Як правило, до тяжких наслідків призводять психологічна неготовність поліцейського до застосування вогнепальної зброї, грубе порушення заходів безпеки під час поводження 3 нею, нездатність адекватно оцінити конкретну обстановку й умови, за яких поліцейський змушений вдаватися до застосування зброї, а також непрогнозована поведінка правопорушника. I якщо навички безпечного поводження зі зброєю, вміння швидко орієнтуватися в обстановці прищеплюються шляхом регулярних і тривалих тренувань, то психологічна підготовка до застосування вогнепальної зброї не може бути вироблена в аудиторії чи під час навчально-тренувальних стрільб у системі службової підготовки.

Актуальність цієї проблеми пов'язана також із тим, що Курс стрільб для поліцейських, затверджений Наказом МВС України від 26 квітня 2019 р. № 334, не враховує варіативність реальних ситуацій, обставини яких суттєво впливають на психологічний стан поліцейського під час вогневого контакту. Якщо під час навчально-тренувальних стрільб курсант чи поліцейський доволі швидко призвичаюється до умов у тирі й кожного наступного тренування вже майже не зважає на навколишню обстановку й не оцінює доцільність застосування зброї, то під час несення служби кожного разу складаються нові умови та обставини, які

1 З’ясувалося, скільки поліцейських загинуло в Україні // Слово і Діло : сайт. 22.01.2018. URL: https://www.slovoidilo.ua/2018/01/22/ novyna/pravo/zyasuvalosya-skilky-policejskyxzahynulo-ukrayini (дата звернення: 11.12.2020). впливають на результативність вогневого контакту і які часто поліцейський може визначити, лише прибувши на місце. До того ж вогневий контакт ускладнюється імовірною появою на лінії вогню сторонніх осіб чи тварин, а також активними діями правопорушника, спрямованими на те, щоб не бути затриманим.

Слід додати, що відповідно до ст. 43 Закону України «Про національну поліцію» застосуванню будь-яких законних заходів примусу має передувати попередження про їх застосування та надання правопорушникові часу, достатнього для виконання вимоги поліцейського, «крім випадку, коли зволікання може спричинити посягання на життя і здоров'я особи чи та/або поліцейського або інші тяжкі наслідки, або в ситуації, що склалася, таке попередження $\epsilon$ невиправданим або неможливим» ${ }^{2}$. Це означає, що поліцейський має миттєво оцінити ситуацію, а також визначити доцільність попереджувальних заходів та ефективність застосування фізичного впливу і спеціальних засобів, які мають передувати застосуванню вогнепальної зброї. Для уникнення тяжких наслідків та успішного затримання правопорушника такі мисленнєві процеси мають тривати долі секунди, до чого поліцейський часто виявляється не готовим.

Таким чином, психологічна готовність поліцейського до застосування вогнепальної зброї є однією з важливих складових у системі загальної та вогневої підготовки.

Виходячи 3 цього, метою дисципліни «Вогнева підготовка» у системі навчання поліцейських має бути не лише прищеплення навичок швидкісного приготування до стрільби та ведення влучної стрільби по нерухомих і рухомих цілях з різних положень, а й формування психічної і тактичної готовності до ефективного застосування вогнепальної зброї, коли виникають підстави, передбачені ст. 46 Закону України «Про Національну поліцію».

Використання і застосування вогнепальної зброї для більшості людей не є буденним явищем, тому перші заняття із ведення вогню викликають у курсантів почуття тривоги, страxy, що спричиняє стан надмірної напруженості психіки стрільця. Постійні та регулярні тренування, а також формування стійких навичок поводження 3 вогнепальною зброєю сприяють подоланню цих перешкод і дозволяють

2 Про Національну поліцію : Закон України від 02.07.2015 № 580-VIII // База даних «Законодавство України» / Верховна Рада України. URL: https://zakon.rada.gov.ua/laws/show/580-19 (дата звернення: 11.12.2020). 
покращити результати виконання вправ, передбачених Курсом стрільб для поліцейських. Однак відмінні результати виконання вправ зі стрільби не забезпечують готовність поліцейського до вогневого контакту зі злочинцем, який, на відміну від мішені в тирі, часто теж озброєний, рухається і прагне діяти на випередження.

До того ж, як зауважує В. Малічевський, серед чинників, які впливають на ефективність діяльності людини в екстремальних умовах, переважають психоемоційні, а саме: функціональний і психологічний стан організму (психічні травми, наявність соматичних захворювань); індивідуально-психологічні особливості (витривалість, рівень тривожності, стійкість до перенапруження й небезпеки); наявність відповідного досвіду, спеціальна підготовленість до дій [4, с. 120-121].

Звісно, цілковито усунути ці фактори неможливо. Однак можна мінімізувати їх вплив на стрільця шляхом упровадження в систему навчальних і тренувальних стрільб методик і технік практичної стрільби, які використовуються у дисциплінах Міжнародної конфедерації практичної стрільби (далі - МКПС).

Практична стрільба в Україні - відносно молодий вид спорту, який, однак, уже виробив сталу систему підготовки стрільця до ведення вогню в незвичних та екстремальних умовах.

Перевагою вправ практичної стрільби, в першу чергу, є мінімальний час на підготовку до пострілу. Так, кобура відкритого типу дозволяє одночасно захопити пістолет і вивільнити його від елементів замикання, витягування пістолета з кобури відбувається разом із вимиканням запобіжника, а винесення зброї на лінію вогню супроводжується досиланням патрона в патронник. Якщо усі ці дії довести до рівня навичок, то поліцейський зможе виконувати їх не замислюючись, що дозволить краще зосередитись на оцінюванні навколишньої обстановки.

Також вправи практичної стрільби охоплюють переміщення стрільця не лише по рівній поверхні, але і з перешкодами, стрільбу в русі або з найменш зручних позицій, стрільбу по рухомих мішенях, використання укриттів, швидке перезаряджання зброї та заміну магазина. Комбінування всіх цих елементів дозволить виробити у поліцейського сталі алгоритми поведінки у подібних умовах та обстановці.

Звісно, Курс стрільб для поліцейських містить вправи на відпрацювання навичок ведення вогню із-за укриттів, в умовах фізичних навантажень, недостатнього освітлення, пересуваючись та змінюючи магазин тощо, од- нак і вони не забезпечують формування низки професійних компетенцій, пов'язаних із психологічною і тактичною готовністю поліцейського до застосування зброї. Під тактичною готовністю мається на увазі швидке й уміле орієнтування на місцевості з метою використання особливостей рельєфу чи побутових предметів для укриття, вміння безпечно і приховано змінювати бойову позицію, в разі потреби відкривати вогонь із незручних позицій тощо. Психологічна готовність визначається здатністю за екстремальних умов правильно оцінити обстановку, яка склалася, й адекватно реагувати на злочинні дії противника.

Більшість фахівців із психології поводження 3 вогнепальною зброєю і тренерівпрактиків поділяють думку, що швидко адаптуватися до кожного конкретного випадку вогневого контакту стрілець може тільки за умови, коли відсутня потреба замислюватися над виконанням простих дій під час вогневого контакту (над правильним триманням пістолета, досиланням патрона в патронник, прицілюванням тощо). Іншими словами, тактична і правова підготовка поліцейського має бути доведена до рівня навичок, коли всі дії виконуються автоматично та не потребують мисленнєвих ресурсів.

Курс стрільб для поліцейських спрямований на формування більшості цих навичок, але він не враховує варіативності сценаріїв реального розвитку подій. Перевага дисциплін МКПС полягає в тому, що вони не мають чітко закріплених і регламентованих вправ, а дозволяють відпрацьовувати окремі стрілецькі елементи, довільно комбінуючи їх, створювати різноманітні сценарії, що сприяє підвищенню результатів стрільця на змаганнях.

До таких стрілецьких елементів, зокрема, належать:

- статичне ураження мішеней із-за правого та лівого укриття, що дозволяє змінювати як положення для стрільби, так і утримання зброї;

- статичне ураження мішеней через занижений (середній) порт, який не дозволяє вести вогонь зі звичної стійки, але й не вимагає переходу в положення на коліно;

- переміщення на середню (до 5 м) і довгу (понад 5 м) відстань без заряджання зброї та з її заряджанням;

- ведення вогню в русі ${ }^{1}$.

1 Стрілецькі елементи // Z\&P Group : сайт. 13.02.2017. URL: https://ipsc-shooting.com/ blog/bazovi_striletski_elementi_101228 (дата звернення: 11.12.2020). 
Елементи практичної стрільби, особливо за вмілого їх комбінування, дозволяють наблизити умови виконання навчально-тренувальних стрільб до ситуацій, коли під час несення служби поліцейський має застосувати вогнепальну зброю, перш за все тим, що стрілець, виконуючи ці вправи, постійно рухається, часто доволі швидко, оскільки результат залежить не тільки від точності ураження мішеней, а й від часу виконання вправ. При цьому рух відбувається як у горизонтальній, так і вертикальній площині: оскільки у вправах можуть використовуватися середні й низькі порти, на шляху стрільця можуть траплятися перешкоди у вигляді тунелів чи естакад, а також нестійких конструкцій. Кожен стрілець має можливість визначати маршрут руху й уражати мішені в довільному порядку, виходячи із власного досвіду й конкретної обстановки. Таким чином, відбувається відпрацювання не лише влучної стрільби, але й нарощується вміння діяти швидко, що часто в реальних ситуаціях вогневого контакту може коштувати поліцейському життя або здоров'я.

Також техніки практичної стрільби дозволяють комбінувати різні елементи, що створює широку варіативність вправ і можливість відтворення найрізноманітніших умов ведення вогню та відпрацювання широкого спектру можливих сценаріїв. Запровадження такої варіативності у системі вогневої підготовки поліцейських дозволить моделювати різні реальні ситуації застосування вогнепальної зброї та сприятиме підвищенню витривалості, стійкості до перенапруження, готовності до раптової зміни обстановки, зумовленої поведінкою противника.

Слід додати, що ефективність цих технік у підвищенні психологічної готовності поліцей- ського до вогневого контакту можлива лише за регулярного і багаторазового відпрацювання тих чи інших елементів, як окремо, так $\mathrm{i}$ в різних комбінаціях. До того ж висока результативність досягається навіть під час тренувань без застосування набоїв. Так, Є. Сорокін стверджує, що для досягнення стійких навичок необхідно повторити ту саму вправу 5000-8000 разів [5, с. 46]. Перевагою елементів практичної стрільби $\epsilon$ те, що багато з них можна відпрацьовувати поза межами спеціально облаштованих навчально-тренувальних полігонів, а отже, вони не вимагають присутності поліцейського в тирі чи спортзалі та не потребують використання набоїв.

\section{Висновки}

Безперечно, впровадження методик і технік практичної стрільби у навчальний процес закладів вищої освіти зі специфічними умовами навчання системи МВС України потребує, в першу чергу, вдосконалення чинного Курсу стрільб для поліцейських. Зокрема, підвищенню психологічної готовності до вогневого контакту сприяла б наявність у Курсі стрільб варіативної складової, яка дозволить викладачам вогневої підготовки враховувати специфіку професійних обов'язків поліцейського та моделювати нетипові ситуації вогневого контакту. Однак уже включення в систему вогневої підготовки елементів практичної стрільби як доповнення до Курсу стрільб не лише поліпшить навички володіння вогнепальною зброєю, а й сприятиме формуванню насамперед психологічної готовності поліцейських до ведення вогню в екстремальних умовах та дозволить знизити ризики настання негативних наслідків як для поліцейських, так і для інших громадян.

\section{Список бібліографічних посилань}

1. Волков Ю. М. Психологічні аспекти застосування вогнепальної зброї поліцейськими на ураження. Науковий вісник Дніпропетровського державного університету внутрішніх справ. 2017. № 4. C. $143-146$.

2. Чеботарьов Е. В. Психологічні аспекти підготовки працівників правоохоронних органів для застосування вогнепальної зброї в екстремальних умовах. Проблеми сучасної психології. 2011. Вип. 13. C. $626-634$.

3. Логачов М. Г. Правові та психологічні аспекти застосування вогнепальної зброї персоналом поліції. Право і Безпека. 2017. № 4 (67). С. 199-204.

4. Малічевський В. І. Психологічні методи вогневої підготовки в підрозділах органів внутрішніх справ МВС України : дис. ... канд. психол. наук : 19.00.06. Київ, 2003. 263 с.

5. Сорокин Е. Израильский стиль боевой стрельбы из пистолета. Психологические аспекты подготовки. Солдат удачи. 1998. № 11. С. 44-46. 


\section{ФЕДОРОВ В. В., ПИСКУНОВА О. Б. РОЛЬ ПРАКТИЧЕСКОЙ СТРЕЛЬБЫ В СИСТЕМЕ ОГНЕВОЙ ПОДГОТОВКИ ПОЛИЦЕЙСКИХ: ПСИХОЛОГИЧЕСКАЯ СОСТАВЛЯЮЩАЯ}

Рассмотрены перспективы внедрения методик и техник практической стрельбы в систему специальной подготовки полицейских. Определен ряд факторов, влияющих на эффективность и результативность огневого контакта. Указано, что огневая подготовка полицейского должна не только прививать первичные навыки обращения с огнестрельным оружием, но и формировать устойчивые алгоритмы действий в тех или иных типичных ситуациях. Некоторые положения этой статьи уже были высказаны в докладе на Международной научно-практической конференции «Путь успеха и перспективы развития (к 26-летию основания Харьковского национального университета внутренних дел)».

Ключевые слова: огневая подготовка, огневой контакт, психологическая готовность к стрельбе, применение огнестрельного оружия, практическая стрельба, огнестрельное оружие.

\section{FEDOROV V. V., PISKUNOVA O. B. ROLE OF PRACTICAL SHOOTING IN THE SYSTEM OF POLICE SHOOTING TRAINING: PSYCHOLOGICAL COMPONENT}

Psychological unpreparedness of police officers to firefight is often the cause of serious consequences, in particular their death. Although much attention has been already paid to the psychological training of law enforcement officers in general and to the use of firearms in the scientific literature, such studies often just outline the problems, but do not suggest the ways to overcome them. The authors of the article aim to analyze the factors influencing the state of psychological readiness of a police officer to use a firearm while performing service duties, and to develop recommendations that should contribute to the formation of a state of psychological readiness, taking into account the specifics of practical shooting. It has been emphasized that firefight requires from a police officer not only skillful handling of weapons, but also a number of thought processes in a situation of partial or complete uncertainty, which affects the psychological readiness to use firearms. The authors have made an analogy between the situations of firefight of police officers while performing service duties and the conditions created for participants in practical shooting competitions. According to the authors, long-term training, regular practice of basic exercises to improve firearms skills, as well as the introduction of variability of scenarios for the deployment of firefight situations using elements of practical shooting can minimize the negative impact on the mental processes of police officers. It has been offered to introduce elements of practical shooting into the system of fire training of police officers and to improve the current Shooting Course, approved by the order of the Ministry of Internal Affairs of Ukraine dated from April 26, 2019, No. 334, which should allow modeling multiple scenarios of police behavior in firefight situations during training shootings and increase the psychological readiness of police officers to use firearms.

Key words: shooting training, fire contact, psychological preparedness to shoot, use of firearms by police, practical shooting, firearms. 